http://www.pakjas.com.pk

\title{
SPATIAL AND TEMPORAL EVALUATION OF DEPTH AND SALINITY OF THE GROUNDWATER IN A LARGE IRRIGATED AREA IN SOUTHERN TURKEY
}

\author{
Harun Kaman ${ }^{1, *}$, Mahmut Cetin ${ }^{2}$ and Cevat Kurda ${ }^{2}$ \\ ${ }^{1}$ Akdeniz University, Faculty of Agriculture, Department of Agricultural Structures and Irrigation, 07058 Antalya, \\ Turkey; ${ }^{2}$ Cukurova University, Faculty of Agriculture, Department of Agricultural Structures and Irrigation, 01330 \\ Adana, Turkey. \\ "Corresponding author's e-mail: hkaman@akdeniz.edu.tr
}

It is of high importance to monitor groundwater level and salinity in wide irrigated farming lands. This is because high levels of groundwater and salinity in irrigated lands are major constraints for sustainable agriculture. Thus, this work undertaken aims at monitoring spatial and temporal changes of groundwater level and salinity in irrigated large farm lands. The research work was implemented in Akarsu Irrigation District (Akarsu ID) which is located in Southern Turkey, Lower Seyhan Plain (LSP) in 2007 hydrologic year. During 2007 hydrologic year, depths to water levels in groundwater wells (m) and groundwater salinity, as electrical conductivity $\left(\mathrm{EC}, \mathrm{dS} \mathrm{m}^{-1}\right)$ were measured through five-month-period; from January to October. The results of depth $(\mathrm{m})$ and salinity analysis $\left(\mathrm{dS} \mathrm{m}^{-1}\right)$ of the groundwater wells were mapped using geographical information system. In addition, cropping pattern and crop water requirements of the study area were specified. The results showed that groundwater reached to a critical threshold level in February because of heavy rains. It was noted that there were not any drainage problems in May. In July, however, the drainage problem was the worst. On the other hand, average groundwater salinity levels were higher in May, in early irrigation season, than July and October. The areas in which groundwater salinity was higher than the critical level (i.e., EC > $5 \mathrm{dS} \mathrm{m}^{-1}$ ) covered $19.2 \%$ of the total area in May, $17.7 \%$ in July, and $15.5 \%$ in September. During the study period, irrigation efficiency was indeed very low, $33.4 \%$. Depending on the research findings, the drainage problem was the highest level in July. It is recommended that present practice of irrigation management is changed.

Keywords: Irrigation, groundwater observation, groundwater depth map, groundwater salinity map, cropping pattern.

\section{INTRODUCTION}

Agricultural sector plays a key role in the socio-economic development of countries. However, irrigation and fertilization is inevitable for the sustainability of agricultural production particularly in the arid and semi-arid regions of the world, including Turkey. Different climatic characteristics prevail in Turkey due to its geographical location. Average annual precipitation is about $643 \mathrm{~mm}$, ranging from $250 \mathrm{~mm}$ in the south-eastern part of the country to over $2500 \mathrm{~mm}$ in the north-eastern Black Sea coastal area. Important fluctuations in precipitation occur from year to year, and precipitation is scarce during the plant growing season in most parts of Turkey indicating that water is a limiting factor for agriculture throughout much of the country. Under these circumstances, irrigation has gradually been expanded since the foundation of Turkish Republic. Turkey has developed its present base of irrigated agriculture gradually over the past 80 years. In this context, irrigation development in Turkey has been carried out by the public sector institutions, namely the General Directorate of State Hydraulic Works (DSI), the Special Provincial Administrations (Rural Services), and by the farmers and groups of farmers (private sector). Obviously
DSI (2014) documented that, as of 2014, 5.9 million ha of the 25.75 million ha irrigable area in Turkey have been equipped with irrigation facilities, of which $61 \%$ has been developed by DSI, $22 \%$ by the Special Provincial Administrations, and $17 \%$ by private sector. The use of irrigation water in the irrigation schemes has not only transformed the former precipitationdependent agriculture into high yield acreage, it has also significantly altered the hydrologic cycle (Ozdogan and Salvucci, 2004) and environmental quality in the irrigated landscapes. In this regard, water-logging, soil and shallow water table salinity, and irrigation induced pollution are a few of the major problems developed under mismanaged irrigation schemes.

As in other practical areas of agricultural production, there could be various problems with irrigation as addressed above. The fact that producers do not know when and how to irrigate and which technique should be used, causes wrong irrigation practices. It is also very common to use primitive lowefficient flood irrigation techniques by cultivators. This situation causes salinity and alkalinity problems and loss of fertile agricultural areas. Ultimately, over-irrigation increases groundwater and salinity levels (Cetin and Kirda, 2003). 
Salinity, which endangers the sustainability of irrigated farming and limits plant production, is a very important problem. Unless salinity is not brought under control, cultivated lands could turn into non-agricultural lands. It is known that farm land loss increases every year because of salinity. Every year, about $40 \times 10^{3}$ ha of fertile-agricultural lands are lost due to the salinity problem (Lamsal et al., 1999) and more than 100 countries are negatively affected from salinity (Szabolcs, 1989).

It is necessary to observe and assess groundwater level and salinity for sustainable agricultural production and water management. In the case that groundwater level rises and reaches plant root-zone, even during a drought period prevails, the groundwater rise must be attributed to excess irrigation. In such conditions, irrigation efficiency must be low due to inferior irrigation technique used (Cetin and Diker, 2003). Groundwater level and salinity can be monitored via 3-4 m deep drainage observation wells in planted or nonplanted farm lands.

Generally, there are special ways to use and cultivate different type of soils (Cetin and Ozcan, 1999). Therefore, existing soil characteristics under irrigation should be maintained. Otherwise, as in many parts of our country and the world, drainage, salinity and alkalinity problems may occur. Salinity in irrigated lands depends on the efficiency and salinity of irrigation water (Aragues et al., 2011). In the Mediterranean basin, salinity in many arid and semi-arid areas threatens irrigated farming (Aragues et al., 2011). Around one-third of irrigated cultivation lands have been substantially affected and will probably be affected from salinity in the near future (Cemek et al., 2006). Many studies have been conducted applying various techniques for monitoring groundwater level and salinity in large areas of irrigated lands (Cemek et al., 2006; Kaman et al., 2011, Cetin et al., 2012; Karatas et al., 2013; Kaman et al., 2013). Findings of those research suggested that although it may be laborious and expensive, the groundwater salinity levels should be continuously monitored in order to take rigors precautions and make recommendations for sustaining irrigated farming (Karatas et al., 2013).

Drainage and groundwater salinity problems exist in irrigated farm lands due to various drawbacks in irrigation water management, e.g. low-efficient irrigation, heavy soil texture and insufficient drainage systems. These problems affect plant production negatively. The aim of this work is to: (a) survey cropping patterns and crop water requirements, groundwater level and salinity changes in irrigated-large-farm lands and, (b) evaluate how the existing water management practices influence on drainage and salinity problems.

\section{MATERIAL AND METHODS}

General characteristics of the study area: This research was conducted in Akarsu Irrigation District (Akarsu ID) which is located in Lower Seyhan Plain (LSP). The LSP covers 213200 ha area, and 174088 ha is suitable for irrigated farming (Cetin and Kirda, 2003). Akarsu ID covers 9495 ha lands. Latitude and longitude of the LSP is $36^{\circ} 51^{\prime} 46^{\prime \prime}-36^{\circ}$ $57^{\prime} 00^{\prime \prime} \mathrm{N}$ and $35^{\circ} 24^{\prime} 10^{\prime \prime}-35^{\circ} 36^{\prime} 34^{\prime \prime} \mathrm{E}$. It is located in the southern Turkey, Karataş, Adana (Figure 1). The area where the work carried out is under irrigation since last 50 years. In 1994, irrigation water management services in the area were transferred to irrigation unions by General Directorate of State Hydraulic Works. However, the farmers in LSP generally use low-efficient surface irrigation techniques.

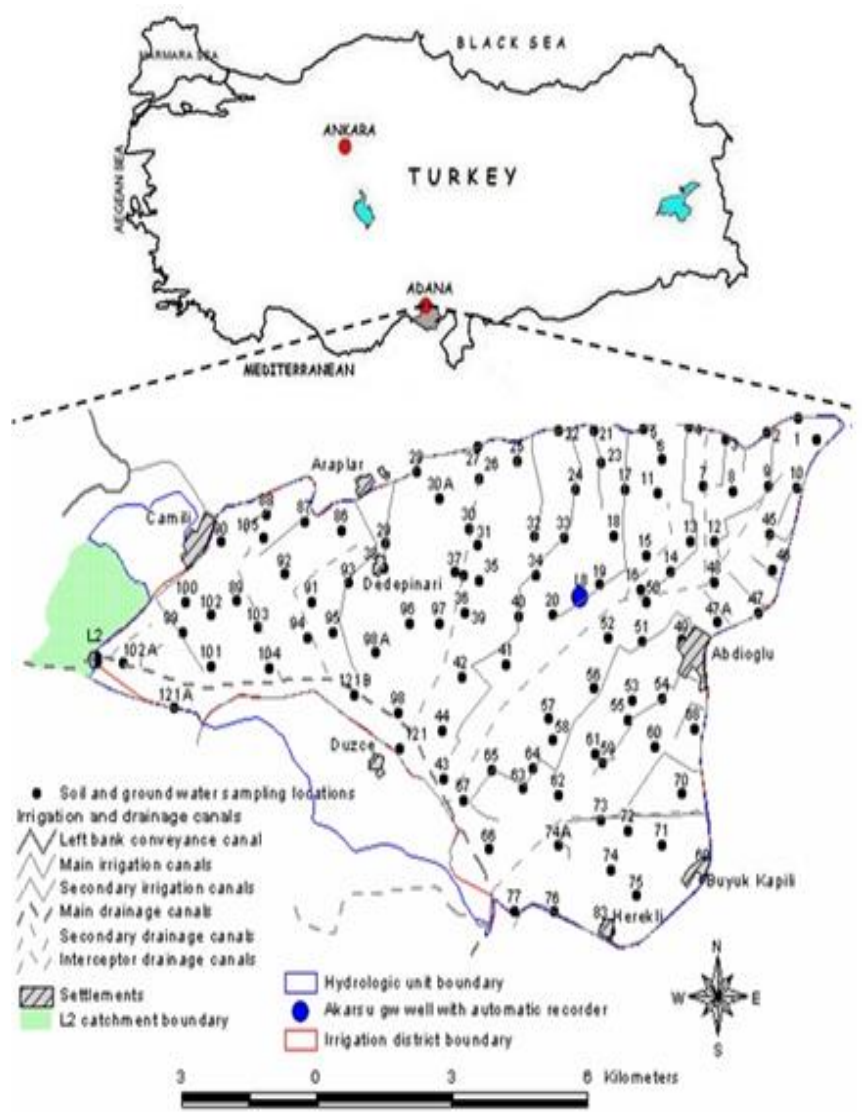

Figure 1. Geographical location of the study areas in Turkey, spatial distribution of groundwater $(G W)$ observation wells $(\bullet)$, and irrigation $(-)$ and drainage (- - - ) canals

Seyhan River, the only water source for the plain which has $6.3 \mathrm{~km}^{3}$ year $^{-1}$ average water flow, has good-quality $(\mathrm{EC}<0.35$ $\mathrm{dS} \mathrm{m}^{-1}$ ) irrigation water. Preponderant soil series in Akarsu ID covers $71 \%$ of the total land area; Arikli 30\%, Incirli $27 \%$ and Yenice 14\% (Dinç et al., 1995).

The area in which the research was conducted is in the Mediterranean climate zone, and summers are hot and dry, and winters are warm and rainy. Long years (60 years) average temperature in the area is $18.8^{\circ} \mathrm{C}$. August is the 
hottest month of the year with $28.1^{\circ} \mathrm{C}$; January is the coldest with $9.9^{\circ} \mathrm{C}$. The area with this climate receives almost all of its precipitation during winter and the precipitation is mostly in the form of rain. The average annual precipitation is about $650 \mathrm{~mm}$. However, distribution of precipitation through the year is not homogenous. Relative humidity reaches high levels in summers due to the rise in temperature and beginning of irrigation season in cultivation areas. In winters, however, relative humidity shows a falling tendency.

Cropping pattern and crop water requirements: Cropping pattern was determined through using both satellite images and field surveying. In this regard, distribution of different field and horticultural crops were monitored and determined for land use types (LUTs) using the low cost ASTER satellite images and GIS in Akarsu ID. In order to determine the parcel distribution pattern of the District, study area maps of 1:5000 scales were digitized by using ArcGIS software. In order to enable a supervised classification of satellite images, numerous ground truth observations were done in growing season, and commonly grown different field crops and orchards were mapped during the field work. The enhanced satellite images were overlaid onto the digitized parcel map for ground observations. The images were printed and checked for all crops of the fields.

Daily reference evapotranspiration (ETo) was calculated from climatological data collected by an automatic weather station located in the central part of the District (L8 in Fig. 1) using the FAO Penman-Monteith method (Allen et al., 1998). Actual evapotranspiration (ETc) from the agricultural fields was estimated by multiplying the weather-based ETo data by crop coefficients $(\mathrm{Kc})$ determined according to the crop type and its growth stage. Detailed information on crop coefficients can be found in Kanber (1982).

Hydrological observations: The hydrological year (HY) starts on the 1st October and ends on the 30th September of the following year. The irrigation season (IS) covers the period from April to September, and the non-irrigation season (NIS) from October to March. In order to evaluate existing irrigation water management regime in the district, irrigation and drainage discharge rates were measured hourly in five gauging stations (four input points and one output point) and three gauging stations (two input and one output points), respectively. Drainage fraction (DF), leaching fraction (LF) and district irrigation efficiency (DIE) were calculated following the procedure given in Cetin et al. (2013) and Ibrikci et al. (2015).

Groundwater sampling for depth and salinity: Adhering strictly to the definition of the hydrological year, the research was conducted in 2007 hydrologic year, between October 1, 2006 and September 30, 2007. After the relevant field and mapping surveys, 108 groundwater wells were constructed in the research area in order to monitor the spatial and temporal changes in groundwater levels and salinity (Fig. 1). Field data in "Magellan Explorist 600" (Thales, 2005) device was evaluated and the UTM coordinates of groundwater wells in the research area were determined via GPS taking Datum=ED50 as a base. Then, in 2007 hydrologic year, depth-to-water table in groundwater wells (m) were measured through five-month-period; January, February, May, July, and October. In parallel with this, water samples were taken from groundwater wells in every measuring time. Electrical conductivity measurements of the water samples (EC, dS m$\left.{ }^{1}\right)$ were carried out in the lab. According to the technique followed by Cetin ve Diker (2003), groundwater depths from soil surface in the groundwater wells (m) and electrical conductivity $\left(\mathrm{dS} \mathrm{m} \mathrm{m}^{-1}\right)$ were used as basic research material. Groundwater depths $(\mathrm{m})$, coordinates, and the results of laboratory analysis $\left(\mathrm{dS} \mathrm{m}^{-1}\right)$ provided the data source evaluated via Geographic Information System (GIS). Based on the principals mentioned by ESRI (1996) and Isaaks and Srivastava (1989) in detail, GIS was used for mapping of depth to groundwater and electrical conductivity.

Coordinates were determined using UTM, Datum=ED50 and central meridian $=33$ parameters (Thales, 2005) in the area via GPS. Inverse Distance Interpolation technique was applied for mapping of depth to groundwater (m) and electrical conductivity $\left(\mathrm{dS} \mathrm{m}^{-1}\right)$ in GIS setting. Therefore, the study area was partitioned with 0.25 ha grids. Variable values in each grid unit were determined with Inverse Distance Interpolation technique. Details of the technique and the parameters used in estimation were described in Cetin et al. (2007).

\section{RESULTS}

Cropping pattern, crop water requirements and existing irrigation water management: The largest acreage of plant in the Akarsu Irrigation District was winter wheat, covering a total area of 3238 ha $(34.1 \%)$ during the 2007 hydrological year. As seen in Figure 2, corn was the dominant irrigated crop, planted either as first crop (29\%) or as a second crop $(5 \%)$ following winter wheat $(34.1 \%)$ in summer.

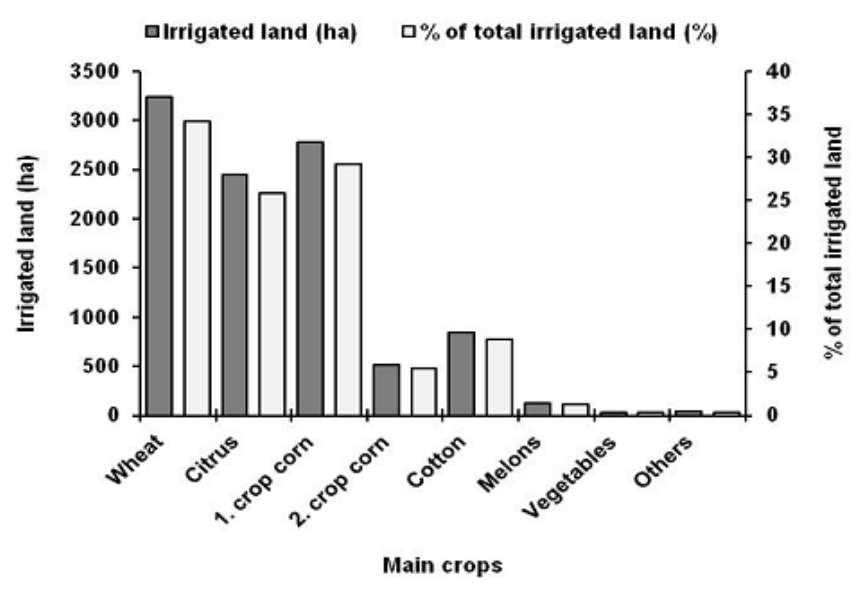

Figure 2. The acreage and percentage of main crops. 
Cotton was planted only $9 \%$ as one of the major irrigated crops, although it was the only major crop, covering more than $90 \%$ of the LSP in 1980s and at the beginning of 1990s. The coverage of citrus orchards (26\%) follows the 1st crop corn. Minor crops which were named as "others" consisted of garlic, onion, potatoes, etc. Spatial distribution of dominated crops was depicted in Figure 3. As seen, citrus orchards were mostly established along Ceyhan River due to the fact that physical and chemical characteristics of the river bank soils are suitable for horticultural crops.

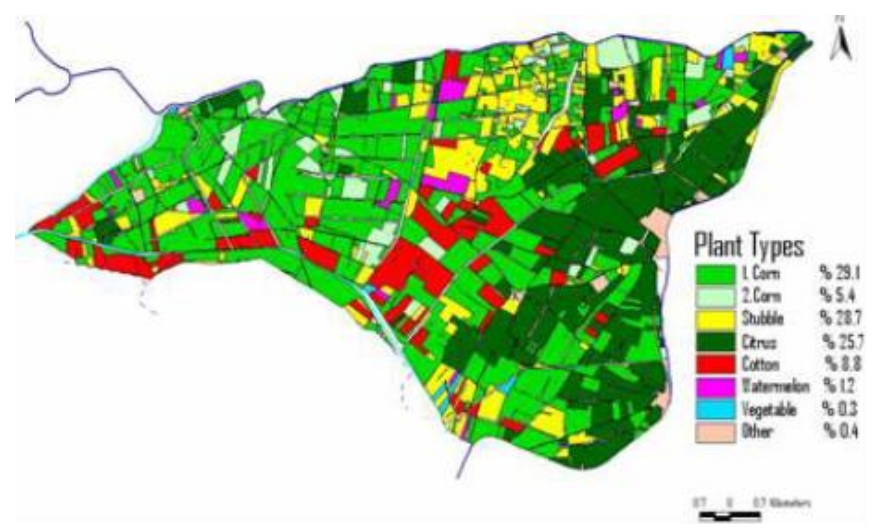

Figure 3. Spatial distribution of main crops.

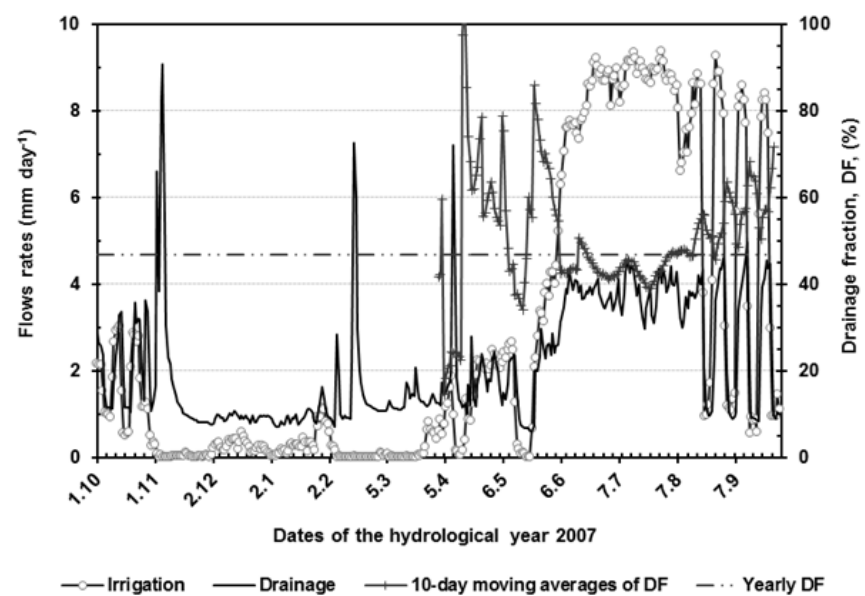

Figure 4. Temporal variations in irrigation water diverted to the District, drainage generated by the District and drainage fraction which is an indication of water management regime in the District.

Hydro-meteorological observations showed that the research area received $676 \mathrm{~mm}$ rainfall in $2007 \mathrm{HY}$, of which 36 percent occurred from October to December in 2006, 62 percent from January to March in 2007, indicating uneven temporal rainfall $(\mathrm{P})$ distribution in the District. However, the total amount of irrigation water (I) diverted to the District, drainage water $(\mathrm{Q})$ generated by the District, and actual evapotranspiration (ETc) from the agricultural fields were determined as 1014,788 , and $710 \mathrm{~mm} \mathrm{y}^{-1}$, respectively. Although only $7 \%$ of I realized during NIS, 34\% of Q occurred in NIS, revealing that $66 \%$ of drainage are due to irrigation water. The higher irrigation water is diverted to the District, the higher drainage is generated from the District (Figure 4), indicating clearly that existing irrigation water management regime is poor and needs some improvements. The district's irrigation efficiency (DIE) was only 33.4\% during the entire hydrological year while it increased to $47.7 \%$ during the irrigation season. Furthermore, leaching fraction (LF) was $58 \%$ in the HY. DIE and LF of the District showed clearly that the irrigation water diverted for the Akarsu ID was wasted as drainage outflow during irrigation season, giving a drainage fraction (DF) as high as $46.7 \%$. However, during the peak irrigation period, i.e., in June and July, DF was observed less than the mean value (Figure 4).

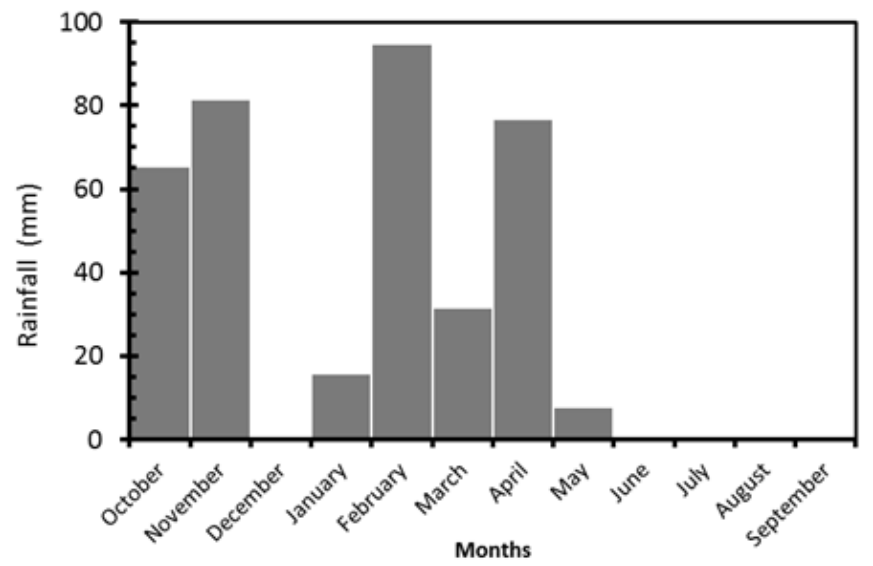

Figure 5. Temporal variability of precipitation in the District.

Changes in groundwater depth: Groundwater depths measured at each sampling period and GW salinity determined were mapped in GIS media. Areal extent of GW depths and salinity were tabulated with spatial analyzing tool of GIS. Additionally, areal averages with standard deviations were given in the related tables. Due to the prevailing drought conditions (recession in drainage flows in Fig. 4 and 5) in December and January (winter time) in which groundwater depth observations were made, mean GW depth was found as the deepest $(1.60 \pm 0.33 \mathrm{~m})$ in January, and the areas with severe drainage problems (GW depth $<1.0 \mathrm{~m}$ ) covered only $3.9 \%$ of Akarsu ID (Figure 6). However, because of the heavy rains, GW depth reached to the critical levels in February (Figure 5). In the rainy period, areas having GW depth $<1.50$ $\mathrm{m}$ reached to $84.8 \%$. The $67.1 \%$ of the study area had the drainage problem ( $\mathrm{GW}$ depth $<1.50 \mathrm{~m}$ ) during the peak irrigation season, and only $5.8 \%$ of the study area was risk free for drainage (GW depth $>2.0 \mathrm{~m}$ ). The extent and severity of the areas having drainage problems can be seen in Figure 7 , as well. 


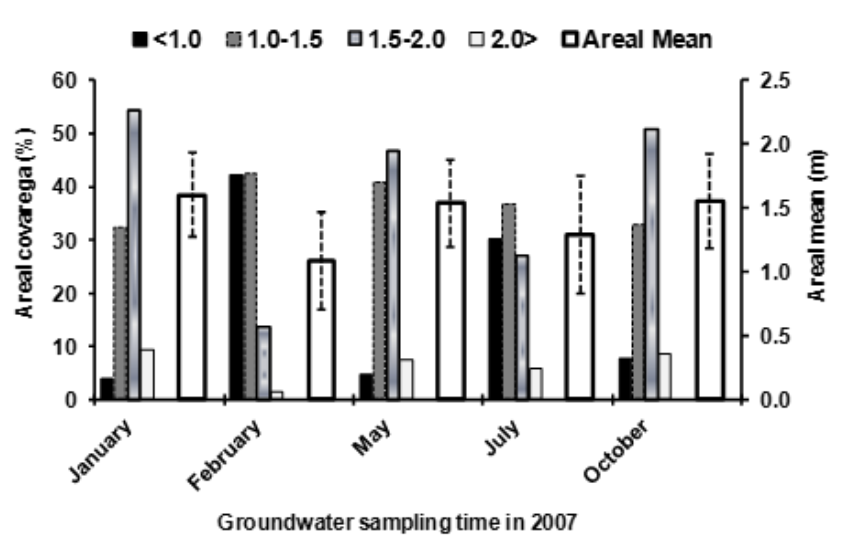

Figure 6. Areal coverage with different groundwater depths.
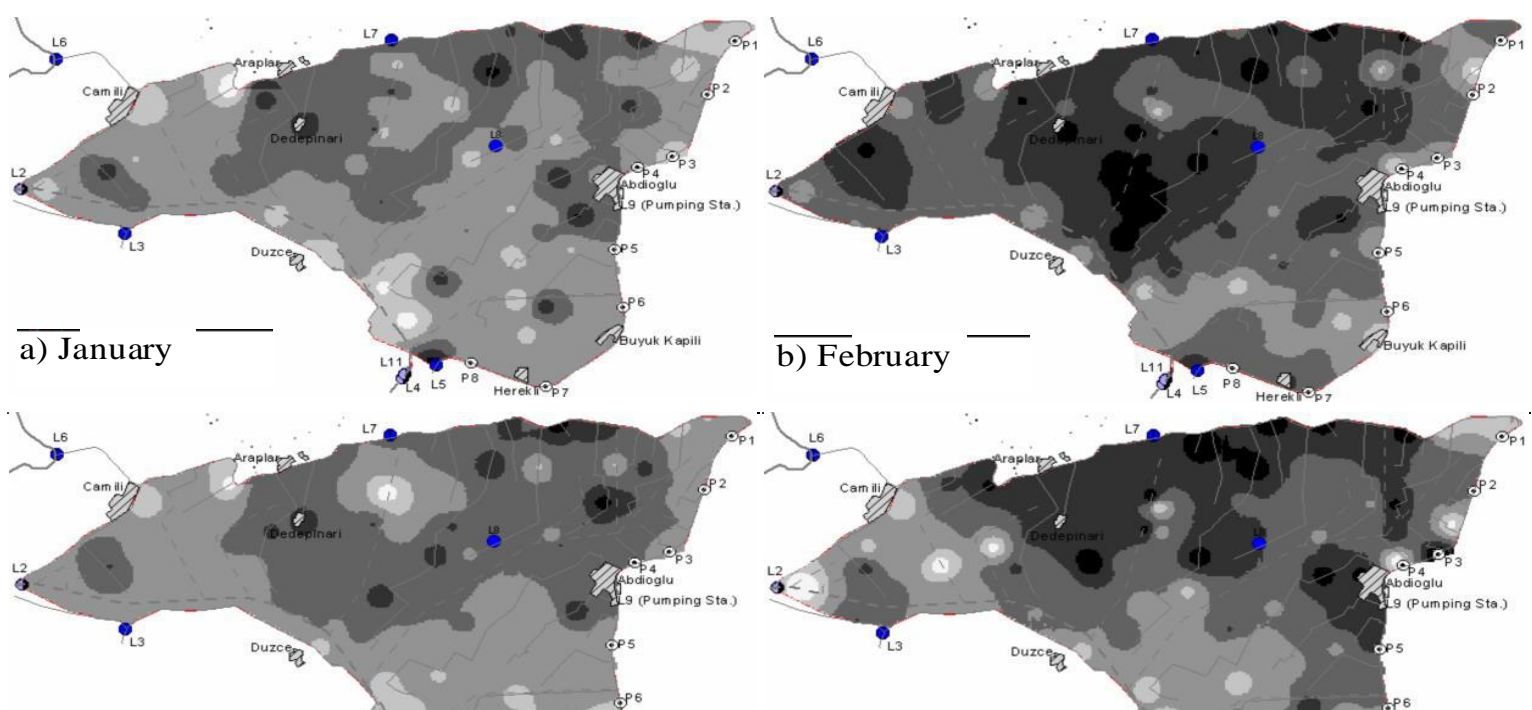

c) May
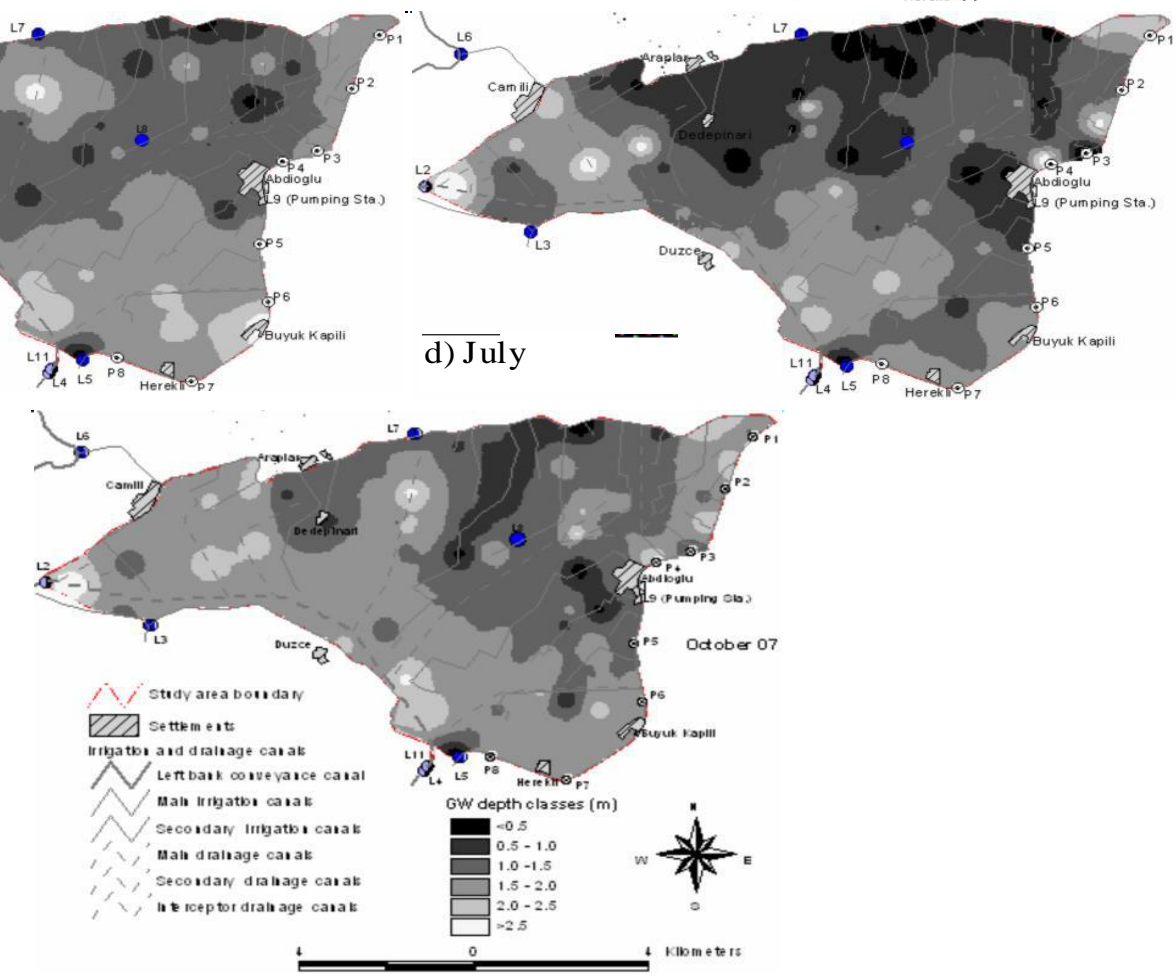

e) October

Figure 7. Spatial and temporal distribution of GW depth. 


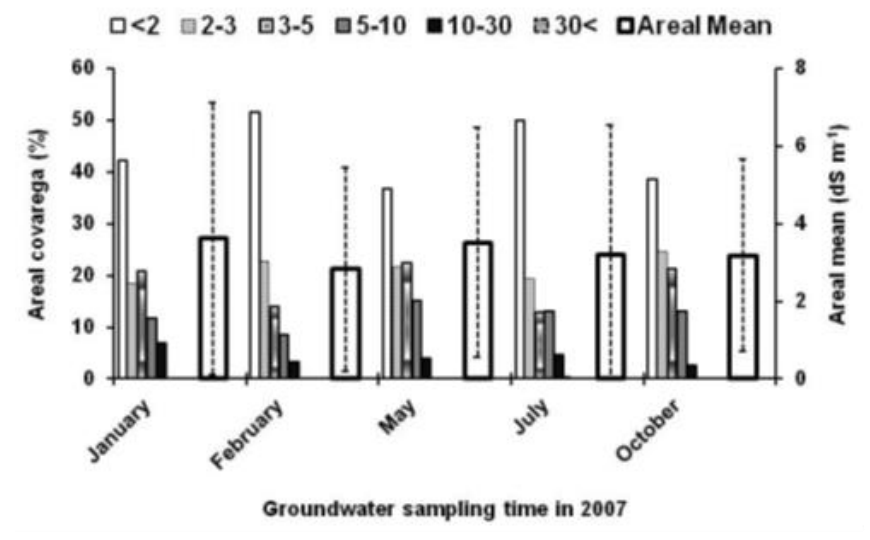

Figure 8. Areal coverage with different GW EC values.

\section{DISCUSSION}

Groundwater depth: Groundwater depth reached a critical threshold in February because of heavy rains (Fig. 6 and 7). On the other hand, the farmers in Akarsu ID applied the highest level of irrigation in July. In the study carried out in Cukurova district by Demir and Antepli (2004), it was stated that irrigation practices reached the highest levels in July. Thus, the drainage problem was the worst in July (Fig. 6 and 7). Groundwater depth measures (Fig. 6 and 7) showed that there was not an important drainage problem in May, the early irrigation season. However, there was a drainage problem (GW depth $<1.0 \mathrm{~m}$ ) in significant part of the research area in July, during the peak irrigation season (Fig. 6 and 7). The results therefore suggest that increase in agricultural water

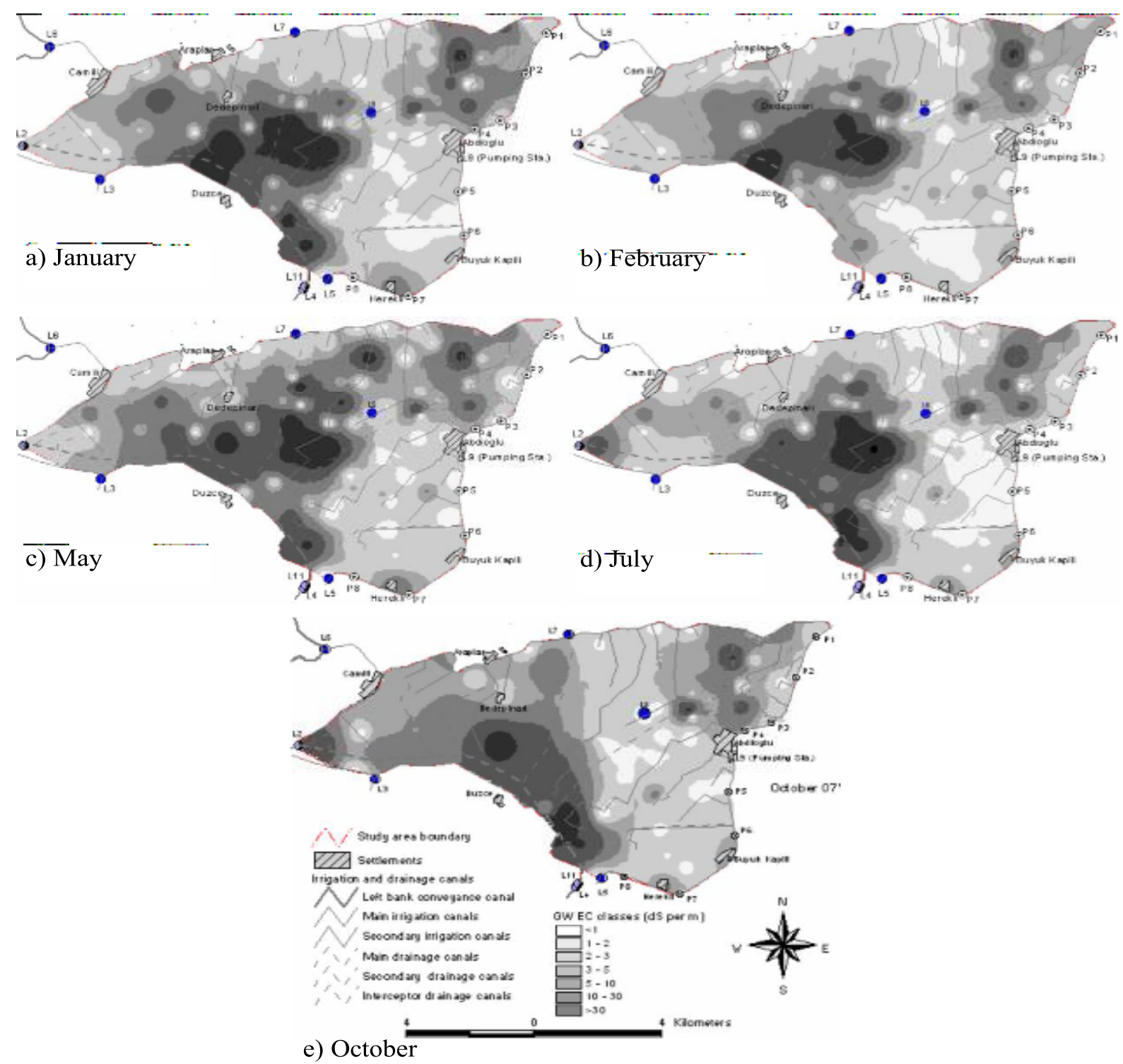

Figure 9. Spatial and temporal distribution of GW salinity. 
usage in July enhances the severity and spread of drainage problem. Findings of this study support the studies conducted by Demir and Antepli (2004), Cetin et al. (2007) in the same area.

Groundwater depth, which was observed just after the heavy precipitation at the end of April (Fig. 5), is influenced by rains in May, the early irrigation season. After May, irrigation practices in the area continue till September. The groundwater depth and drainage problem therefore is influenced significantly by irrigation management practices.

Groundwater salinity: Average groundwater salinity levels were higher in May, the beginning of the irrigation season than that in July and October (Fig. 8). Similarly, spatial and temporal changes in groundwater salinity levels were the highest in May (Fig. 9). It was noted that groundwater salinity levels were generally low in July, during the peak irrigation season. Excess irrigation, especially during peak irrigation season, decreased groundwater EC.

Spread of the areas, where groundwater salinity were higher than $5 \mathrm{dS} \mathrm{m}^{-1}$ which is considered as the critical EC level for drainage engineering work (Cetin and Ozcan, 1999; Cetin and Kirda, 2003; Cetin and Diker, 2003), was 19.2\% in May, $17.7 \%$ in July, and $15.5 \%$ in October (Fig. 8). The lowest groundwater salinity levels (in the order of 3-5 dS m $\mathrm{m}^{-1}$ ) were measured in July during the irrigation season (Fig. 8).

Cemek et al. (2006) stated that nearly one-third of irrigated areas have been globally affected with salinity. Similarly, in the Mediterranean basin, salinity in many arid and semi-arid areas threatens irrigated farming (Aragues et al., 2011). It was shown that the salinity risk may be result of highly saline groundwater, lack of drainage, salinity and alkalinity problems (FAO, 2001; Cetin and Kirda, 2003; Demir and Antepli, 2004). On the other hand, Aragues et al. (2011) showed that salinity in the irrigated areas may be results of poor irrigation management and use of surface irrigation methods of low efficiency and salinity of irrigation water.

Conclusions: Drainage problem reached the highest level during the peak irrigation season in July. It was noted that the areas with GW salinity higher than the critical level $(\mathrm{EC}>5$ $\mathrm{dS} \mathrm{m}{ }^{-1}$ ) covered $19.2 \%$ of the total area in May, $17.7 \%$ in July, and $15.5 \%$ in September. The average irrigation efficiency was indeed very low, only 33.4\%. High GW levels in July, during the peak irrigation season, implied excess-irrigation water application, which therefore caused both low irrigation and crop water-use efficiency.

The irrigation scheme in the Akarsu ID is managed based on "continuous flow system" under which there is always water flow existing in secondary and tertiary irrigation channels, and the growers are supposed to continue irrigation practices day and night. Unfortunately, the growers generally irrigate their fields during daytime and therefore irrigation-water in the system is simply lost as drainage outflow during the night. On the contrary, there is endless complain from the growers that their share of irrigation water is not enough. It is recommended that the authorities in charge of irrigation management in the area should find ways of promoting nocturnal irrigation practices and additionally supporting growers for replacing surface irrigation methods either with sprinkler or low pressure drip irrigation methods.

Acknowledgements: This work was funded by European Union, through project QUALIWATER: Diagnosis and Control of Salinity and Nitrate Pollution in Mediterranean Irrigated Agriculture (Project No: INCO-CT-2005-015031) and by Cukurova University Academic Research Support (Project No: ZF2006KAP1). The authors also would like to thank the Research Fund of Akdeniz University for its partial support. Additionally, assistance provided by Çukurova University Faculty Staff H. Ibrikci, M. Dingil, E. Oztekin, E. Karnez, H. Oguz, S. Sesveren, O. F. Karaca is gratefully acknowledged.

\section{REFERENCES}

Allen, R.G., L.S. Pereira, D. Raes and M. Smith. 1998. Crop evapotranspiration. Guidelines for computing crop water requirements. Food and Agricultural Organization of the United Nations, Irrig. and Drainage Paper 56, FAO, Rome.

Aragues, R., V. Urdanoz, M. Çetin, C. Kirda, H. Daghari, W. Ltifi, M. Lahlou and A. Douaik. 2011. Soil salinity related to physical soil characteristics and irrigation management in four Mediterranean irrigation districts. Agric. Water Manage. 98:959-966.

Cemek, B., M. Guler and H. Arslan. 2006. Determination of salinity distribution using GIS in Bafra plain right land irrigated area. Atatürk Üniv. Ziraat Fak. Derg. 37:63-72.

Cetin, M., H. Ibrikci, C. Kirda, H. Kaman, E. Karnez, J. Ryan, S. Topcu, M.E. Oztekin, M. Dingil and S. Sesveren. 2012. Using an electromagnetic sensor combined with geographic information systems to monitor soil salinity in an area of southern Turkey irrigated with drainage water. Fres. Env. Bulletin. 21:1133-1145.

Cetin, M. and C. Kirda. 2003. Spatial and temporal changes of soil salinity in a cotton field irrigated with low-quality water. J. Hyd. 272:238-249.

Cetin, M. and K. Diker. 2003. Assessing drainage problem areas by GIS: A case study in the Eastern Mediterranean Region of Turkey. Irrig. Drainage 52:343-353.

Cetin, M., W.A. Flugel, H. Ibrikci, T. Nagano, B. Tilkici, R. Aragues and E. Karnez. 2013. Sustainability of agricultural water management: A case study in southern Turkey. Abstract Volume, p.157. First World Irrigation Forum and $64^{\text {th }}$ International Executive Council Meeting, 29 September-5 October 2013, Mardin, Turkey.

Çetin, M. and H. Ozcan. 1999. Problems encountered in the irrigated and non-irrigated areas of the Lower Seyhan 
Plain and recommendations for solution: A case study. Tr. J. Agric. For. 23:207-217.

Çetin, M., C. Kirda, H. Efe and S. Topçu. 2007. Aşagi Seyhan Ovasi'nda taban suyu derinligi sulama ilişkilerinin coğrafi bilgi sistemi ile irdelenmesi. (in Turkish) V. Ulusal Hidroloji Kongresi Bildiriler Kitab1, Orta Doğu Teknik Üniversitesi, 5-7 Eylül 2007, Ankara.

Demir, N. and N. Antepli. 2004. Aşağı Seyhan Ovası sulamas1 taban suyu ve tuzluluk problemleri değerlendirme çalışması. (in Turkish) Sulanan Alanlarda Tuzluluk Yönetimi Sempozyumu, 20-21 Mayıs 2004, DSİ Genel Müdürlüğü, Ankara.

Dinc, U., M. Sari, S. Şenol, S. Kapur, M. Sayın, M. Derici, V. Çavuşgil, M. Gök, M. Aydin, H. Ekinci, N. Ağca and E. Schlichting. 1995. Çukurova Bölgesi Topraklari. (in Turkish) Çukurova Üniversitesi Ziraat Fakültesi yardimci ders kitabi, No:26, Adana.

DSI. 2014. Water and DSI. General Directorate of State Hydraulic Works (DSI) Printing Office, Ankara, Turkey.

ESRI. 1996. Using Arcview GIS. Environmental System Research Institute, Inc., Redlands, CA, USA.

FAO. 2001. Drainage and sustainability. IPTRID Issues Paper No. 3, Food and Agriculture Organization of the United Nations, Rome, Italy.

Ibrikci, H., M. Cetin, E. Karnez, W.A. Flügel, B. Tilkici, Y. Bulbul and J. Ryan. 2015. Irrigation-induced nitrate losses assessed in a Mediterranean irrigation district. Agric. Water Manage. 148:223-231.

Isaaks, E.H. and R.M. Srivastava. 1989. An Introduction to Applied Geostatistics. Oxford University Press, Inc., New York.
Karatas, B.S., G. Camoglu and M.K. Olgen. 2013. Spatiotemporal trend analysis of the depth and salinity of the groundwater, using geostatistics integrated with GIS, of the Menemen Irrigation System, Western Turkey. Ekoloji. 22:36-47.

Kaman, H., M. Çetin and C. Kırda. 2011. Monitoring and assessing of changes in soil and groundwater salinity of Yemisli Irrigation District of Turkey using low quality irrigation water. Sci. Res. Essays 6:1388-1396.

Kaman, H., M. Cetin, C. Kirda, A. Kurunc and S. Sesveren. 2013. Using electromagnetic induction technique to determine soil salinity within layers of varying depths: A case study in the Mediterranean farmlands, Turkey. Fres. Env. Bull. 22:2554-2566.

Kanber, R., 1982. Türkiye'de sulanan bitkilerin su tüketim rehberi (in Turkish) In: TOPRAKSUGenel Müdürlügü Yay., No. 718, TOPRAKSU Genel Müdürlügü Publishing, Ankara, Turkey.

Lamsal, K., G.N. Paudyal and M. Saeed. 1999. Model for assessing impact of salinity on soil water availability and crop yield. Agric. Water Manage. 41:57-70.

Ozdogan, M. and G.D. Salvucci. 2004. Irrigation-induced changes in potential evapotranspiration in southeastern Turkey: Test and application of Bouchet's complementary hypothesis. Water Resour. Res. 40:(W04301) 1-12.

Szabolcs, I. 1989. Salt-affected soils. CRC Press, Fla., p.274, Inc. Boca Raton.

Thales. 2005. Magellan eXplorist 600 Reference Manual, Thales S.A., USA. 